\title{
Markers of bone turnover in patients with differentiated thyroid cancer with and following withdrawal of thyroxine suppressive therapy
}

\author{
Jukka Toivonen $^{1}$, Riitta Tähtelä ${ }^{2}$, Kalevi Laitinen ${ }^{3}$ Juha Risteli $^{4}$ and Matti J Välimäki ${ }^{1,2}$ \\ ${ }^{1}$ Department of Medicine, Helsinki University Central Hospital, Helsinki, Finland, ${ }^{2}$ United Laboratories, Helsinki, Finland, ${ }^{3}$ Clinical Research, \\ Leiras Oy, Helsinki, Finland and ${ }^{4}$ Departments of Medical Biochemistry and Clinical Chemistry, University of Oulu, Finland
}

(Correspondence should be addressed to M Välimäki, Department of Medicine, Helsinki University Central Hospital, FIN-O0290 Helsinki, Finland)

\begin{abstract}
Objective: To study whether levothyroxine $\left(\mathrm{LT}_{4}\right)$ suppressive therapy exposes patients with differentiated thyroid cancer (TC) to an increased risk of osteoporosis.

Design and Methods: Markers of bone formation (serum alkaline phosphatase (ALP), osteocalcin (OC), type I procollagen carboxyterminal (PICP) and aminoterminal (PINP) propeptide) and resorption (serum type I collagen carboxyterminal telopeptide (ICTP) and urine hydroxyproline (HOP)), as well as serum intact parathyroid hormone (PTH), 25-hydroxyvitamin D, and 1,25-dihydroxyvitamin $\mathrm{D}\left(1,25(\mathrm{OH})_{2}-\mathrm{D}\right)$ were measured in 29 patients ( 25 women, 4 men) with a median age of 45 years, and in 38 age- and sexmatched controls. In a subgroup of 14 patients the measurements were repeated after 5 weeks' interruption of $\mathrm{LT}_{4}$ therapy. Since the primary treatment of TC the patients had used TSH suppressive doses of $\mathrm{LT}_{4}$ (a mean daily dose of $215 \mu \mathrm{g}$ ) for 9 to 11 years. The bone mineral density (BMD) of patients and controls was measured by dual energy X-ray absorptiometry.

Results: When on $\mathrm{T}_{4}$ therapy, patients had significantly higher mean levels of ALP $(+21 \%, P<0.05)$, OC $(+35 \%, P<0.01)$, PICP $(+10 \%, P<0.05)$, PINP $(+46 \%, P<0.001)$, ICTP $(+21 \%, P<0.05)$, and HOP $(+37 \%, P<0.001)$ compared with controls. After stopping treatment, OC $(-42 \%, P<0.001)$, PINP $(-7 \%, P<0.05)$, and ICTP $(-54 \%, P<0.001)$ decreased, whereas PICP $(+24 \%, P<0.001)$ and $1,25-$ $(\mathrm{OH})_{2} \mathrm{D}(+29 \%, P<0.01)$ increased. BMD of the lumbar spine and the upper femur was similar in patients and controls.

Conclusions: Patients with differentiated TC have high bone turnover when on $\mathrm{LT}_{4}$ suppressive therapy. After withdrawing treatment both bone formation and resorption decrease acutely. During development of hypothyroidism, serum PICP and PINP, which form from the same type I procollagen molecule and should change similarly, behaved differently. This may be due to different effects of hypothyroidism on their removal through separate receptors in the liver.
\end{abstract}

European Journal of Endocrinology 138 667-673

\section{Introduction}

A recent meta-analysis of the available cross-sectional studies showed that in postmenopausal women levothyroxine $\left(\mathrm{LT}_{4}\right)$, in a dose leading to reduced serum thyroid stimulating hormone (TSH), resulted in a significant excess of annual bone loss of $0.91 \% /$ year compared with control women; the same was not true for premenopausal women (1). The significance of this finding in terms of risk for fractures is uncertain (2-4). Endogenous thyrotoxicosis leads to increased bone turnover, which is reflected both in markers of bone formation (such as serum osteocalcin (OC) and bonespecific alkaline phosphatase (B-ALP)), and in those of bone resorption (e.g. urinary pyridinoline cross-link (Pyr) excretion) (5). Although in patients on thyroxine suppressive therapy no thorough analysis of these markers has been performed, scattered data available point to increased bone turnover $(6-10)$. However, when $\mathrm{LT}_{4}$ suppressive therapy was carefully monitored, the rate of bone metabolism appeared to be normal (11). In the present study we used a fairly comprehensive panel of markers of bone formation and resorption to establish bone turnover rate in patients who had been on thyroxine suppressive therapy since primary treatment of thyroid cancer. We also studied the behavior of these markers during iatrogenic hypothyroidism due to withdrawing $\mathrm{LT}_{4}$ replacement therapy for five weeks.

\section{Subjects and methods \\ Patients}

The study group consisted of 25 women and 4 men. They were compared with 38 healthy age- and sex-matched 
controls who were not using any drugs; female controls were also matched for menopausal status and years since menopause. Of the women, 10 were postmenopausal and 15 premenopausal; none of the postmenopausal women was using estrogen replacement therapy. The patients had had thyroid cancer 9 to 11 years before the study. It had been treated with near total thyroidectomy followed by radioiodine ablation in most patients. Since the primary treatment, the patients had used thyroxine in doses sufficient to render their serum TSH level undetectable as assessed with the second generation test (detection limit $0.05 \mathrm{mU} / \mathrm{l}$ ). Except for thyroxine, the patients were not using any drugs and they did not have any other diseases known to affect bone and calcium metabolism.

\section{Design}

The study was approved by the Ethical Committee of the Third Department of Medicine, Helsinki University Central Hospital, and informed consent was obtained from the subjects. Each patient underwent a detailed physical examination. Bone mineral density (BMD) was measured at the lumbar spine and at three proximal femoral sites. After a 12-h overnight fast, blood was sampled for the determination of serum free thyroxine $\left(\mathrm{FT}_{4}\right)$, free tri-iodothyronine $\left(\mathrm{FT}_{3}\right)$, TSH, sex hormonebinding globulin (SHBG), total calcium, magnesium, phosphate, albumin, creatinine, alkaline phosphatase and its isoenzymes, intact parathyroid hormone (iPTH), OC, type I procollagen carboxyterminal (PICP) and aminoterminal (PINP) propeptide, type I collagen carboxyterminal telopetide (ICTP), 25-hydroxyvitamin D (25-OH-D), and 1,25-dihydroxyvitamin D $\left(1,25(\mathrm{OH})_{2}-\mathrm{D}\right)$. Twenty-four-hour urine was collected during the second day of a diet without gelatin for the determination of hydroxyproline (HOP), creatinine, calcium, magnesium, and phosphate. In a subgroup of 14 patients (10 women, 4 men) thyroxine treatment was stopped after the basic evaluation, and blood and urine sampling for the determination of markers of calcium and bone metabolism was repeated after five weeks without thyroxine.

\section{Assays}

$\mathrm{FT}_{4}$ and $\mathrm{FT}_{3}$ were determined using a direct equilibrium method (12). Immunoradiometric assays (IRMA) were used for the determination of TSH (Behringswerke, Marburg, Germany) and SHBG (Orion Diagnostica, Turku, Finland). For the determination of vitamin D metabolites, serum was extracted with acetonitrile, and the metabolites were purified chromatographically using SepPak $\mathrm{C}_{18}$ cartridges; acetonitrile was used for elution. The metabolites were separated using SepPak Silica cartridges and hexane/isopropanol for elution. Both 25-OH-D and $1,25(\mathrm{OH})_{2}-\mathrm{D}$ were determined by saturation analysis using kits from Amersham International plc, Amersham, Bucks, UK. Intact PTH in serum was measured by IRMA using kits from Nichols Institute, San Juan Capistrano, CA, USA. The same manufacturer's RIA kit with an antiserum to human osteocalcin raised in rabbits was employed to measure serum osteocalcin. PICP, PINP (13) and ICTP (14) were determined by RIA kits from Orion Diagnostica, Espoo, Finland. The intra-assay and interassay coefficients of variation for all the above-mentioned assays ranged from 3 to $9 \%$. ALP isoenzymes were determined using a kit from Boehringer Mannheim $\mathrm{GmbH}$, Mannheim, Germany, in which bone-specific isoenzyme is precipitated by lectin, and bone ALP activity is calculated from total and residual ALP activity (15). The intra-assay and interassay coefficients of variation for the assay were $4 \%$ and 5\% respectively. The results were checked by semiquantitative estimation using separation of the isoenzymes by polyacrylamide gel electrophoresis. Urinary HOP was determined by the method of Prockop and Udenfriend (16).

Serum ALP, calcium, magnesium, phosphate, albumin, and creatinine as well as urinary creatinine, calcium, magnesium, and phosphate were determined by routine methods. Albumin-corrected serum calcium was calculated using the equation: corrected calcium $=$ total calcium $-0.02 \times($ serum albumin $(\mathrm{g} / \mathrm{l})-46)$.

\section{Bone mineral density measurements}

BMD of the lumbar spine (lumbar vertebrae L1-L4) and of the proximal femur sites (the femoral neck, Ward's triangle and the trochanter area) was measured by dual energy X-ray absorptiometry using a Hologic QDR1000 densitometer (Hologic Inc., Waltham, MA, USA). At these four measurement sites, the precision of the method (coefficient of variation) was $0.9,1.2,2.7$ and $2.4 \%$ respectively.

\section{Statistics}

The data with normal distributions are expressed as means \pm s.D., otherwise as medians with ranges. For consistency, in Figs 1 and 2 the variables are presented using medians and interquartile ranges. Student's twosided two-group $t$-test (comparison of patients with controls) or paired $t$-test (effect of stopping $\mathrm{T}_{4}$ replacement therapy) was used to analyse normally distributed data; if the assumptions for these analyses failed, MannWhitney rank sum test and Wilcoxon signed rank test were used as appropriate. Two-way analysis of variance was used to study the possible effects of sex (apart from group) on BMD. Spearman rank order correlations were calculated between serum free thyroid hormones and bone markers. SigmaStat for Windows software (version 1.0, Jandel Scientific, Erkrath, Germany) was used in the analysis. 

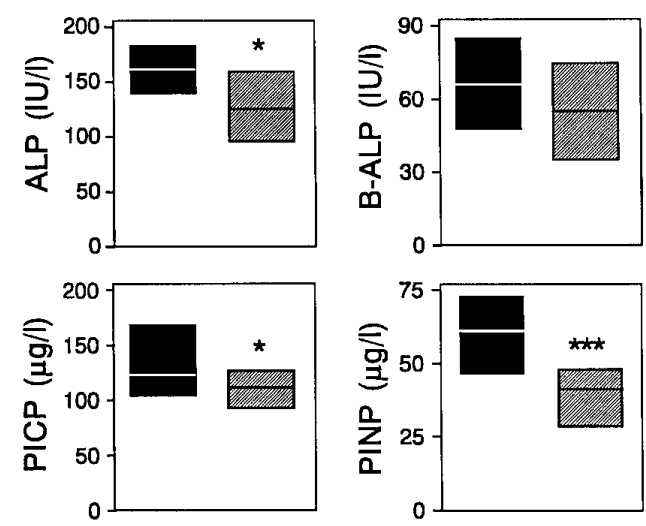

\section{Results}

\section{Baseline characteristics}

The baseline characteristics for patients and controls are given in Table 1. Patients and controls were of similar height, weight, and body mass index (BMI). The mean dose of thyroxine used by the patients was $215 \mu \mathrm{g}$ daily. As expected, patients and controls differed from each other with respect to serum $\mathrm{FT}_{4}, \mathrm{FT}_{3}$, and TSH. The serum concentrations of SHBG, creatinine, and albumin were similar in patients and controls, but that of liver ALP was increased in patients.

\section{Markers of bone and calcium metabolism}

The values for the markers of bone and calcium metabolism in patients and controls are presented in Table 2 and in Figs 1 and 2. Of the markers of bone formation, the patients had significantly higher mean or median levels of ALP $(+21 \%, P<0.05)$, OC $(+35 \%$, $P<0.01)$, PICP $(+10 \%, P<0.05)$, and PINP $(+46 \%$, $P<0.001)$ compared with controls. The markers of bone resorption, serum ICTP $(+21 \%, P<0.05)$ and urinary excretion of HOP $(+37 \%, P<0.001)$ were also higher in patients than in controls. Patients had greater mean urinary excretion of phosphate $(+23 \%, P<0.05)$ and magnesium $(+28 \%, P<0.05)$. The other parameters of calcium and mineral metabolism were similar in patients and controls. There were no statistically significant correlations between $\mathrm{FT}_{4}, \mathrm{FT}_{3}$ and any of the bone markers.

When pre- and postmenopausal female patients were compared separately with their respective controls, serum PINP and urinary HOP were increased in both patient groups, whereas serum OC and ICTP were only increased in premenopausal women (Table 3).

\section{Effects of withdrawing thyroxine replacement on parameters of bone turnover}

Five weeks after withdrawal of $\mathrm{LT}_{4}$ treatment the mean serum levels of OC $(-42 \%, P<0.001)$, PINP $(-7 \%$, $P<0.05)$, and ICTP $(-54 \%, P<0.001)$ decreased, whereas those of PICP $(+24 \%, \quad P<0.001)$ and $1,25(\mathrm{OH})_{2}-\mathrm{D} \quad(+29 \%, \quad P<0.01)$ increased (Fig. 3). PICP and PINP values for individual patients on and off thyroxine suppressive therapy are presented in Fig. 4. Mean serum concentrations of 25-OH-D and iPTH did not change (data not shown).

\section{Bone mineral density}

The whole patient population did not differ from controls with respect to BMD at any of the four measurement sites (the lumbar spine, the femoral neck, the trochanter and Ward's triangle). This was also the case when pre- and postmenopausal women were compared with their respective controls (Table 4).
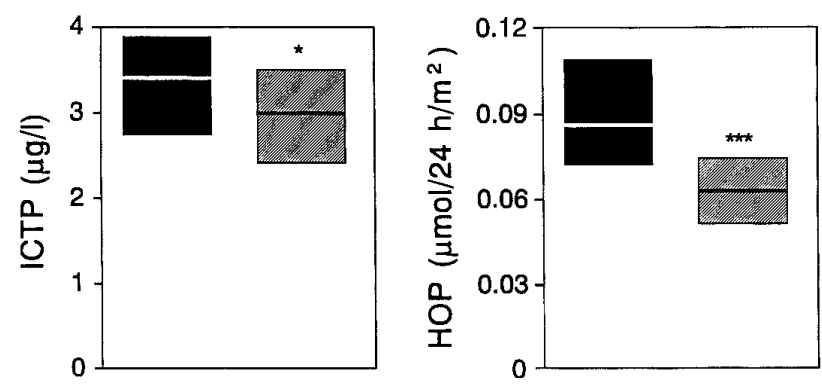

Eatients

通 Controls

Figure 2 Markers of bone resorption (median \pm interquartile ranges) in patients and controls. ${ }^{*} P<0.05,{ }^{* * \star} P<0.001$ for differences between patients and controls. 
Table 1 The baseline characteristics for patients and controls (mean \pm S.D. or median with ranges)

\begin{tabular}{lll}
\hline & \multicolumn{1}{c}{ Patients } & \multicolumn{1}{c}{ Controls } \\
\hline Age $($ years $)$ & $45(27-71)$ & $43(26-65)$ \\
Height $(\mathrm{cm})$ & $168(153-193)$ & $166(150-185)$ \\
Weight $(\mathrm{kg})$ & $66(52-103)$ & $64(46-90)$ \\
$\mathrm{BMI}\left(\mathrm{kg} / \mathrm{m}^{2}\right)$ & $23.7(19.8-32.6)$ & $23.5(18.0-35.0)$ \\
$\mathrm{T}_{4}$ dose $(\mu \mathrm{g} /$ day $)$ & $215 \pm 53$ & \multicolumn{1}{c}{-} \\
$\mathrm{FT}_{4}(\mathrm{nmol} / \mathrm{l})$ & $20.5(13-36)^{\star * *}$ & $13.1(8-24)$ \\
$\mathrm{FT}_{3}(\mathrm{pmol} / \mathrm{l})$ & $6.3(3.9-7.7)^{\star *}$ & $5.0(4.1-5.7)$ \\
$\mathrm{TSH}^{* *}(\mathrm{mU} / \mathrm{l})$ & $<0.05^{* * *}$ & $2.4(0.06-4.1)$ \\
$\mathrm{SHBG}(\mathrm{nmol} / \mathrm{l})$ & $67(21-273)$ & $64(29-170)$ \\
Liver ALP $(\mathrm{IU} / \mathrm{l})$ & $93 \pm 39^{*}$ & $74 \pm 39$ \\
Creatinine $(\mu \mathrm{mol} / \mathrm{l})$ & $79 \pm 10$ & $80 \pm 9.9$ \\
Albumin $(\mathrm{g} / \mathrm{l})$ & $40 \pm 3.4$ & $40 \pm 2.8$ \\
\hline
\end{tabular}

${ }^{*} P<0.05,{ }^{* *} P<0.01,{ }^{* * *} P<0.001$ for differences between patients and controls.

\section{Discussion}

As assessed by a comprehensive range of markers of bone turnover, patients on thyroxine suppressive therapy showed increased rates of both bone formation and resorption. After cessation of thyroxine replacement the turnover rate decreased acutely.

Previous findings of increased serum levels of osteocalcin and alkaline phosphatase and urinary excretion of hydroxyproline $(6,7,9,10)$ are extended by the observation that two other markers of bone formation, PICP and PINP, and a marker of bone resorption, ICTP, were also elevated in patients using TSH suppressive doses of $\mathrm{LT}_{4}$. Instead of trying to use the smallest dose of $\mathrm{LT}_{4}$ sufficient to keep serum TSH undetectable, we administered standard doses of thyroxine to the present patients. Consequently, the mean thyroxine dose used $(215 \mu \mathrm{g}$ daily) was $60 \mu \mathrm{g}$ higher than in the study of Marcocci et al. (11), in which $\mathrm{LT}_{4}$ suppressive therapy was carefully monitored by using the smallest dose necessary to suppress serum TSH below the detection limit of the assay used $(0.07 \mathrm{mU} / \mathrm{l})$. Interestingly, in that study (11) the rate of bone formation and resorption as assessed by serum osteocalcin and ICTP did not differ from normal. Although the normal BMD found in the present patients does not support the idea that accelerated bone turnover increases the risk of osteoporosis, this possibility does, however, exist and thus small adjustments in the thyroxine dose to normalize bone turnover rate may be rational. Note that in a study by Schneider et al. (17) postmenopausal women taking daily $\mathrm{LT}_{4}$ suppressive doses of $200 \mu \mathrm{g}$ or more had lower BMD at the midshaft radius and hip compared with those taking lower doses.

Although we did not use novel and possibly the most bone-specific urine markers to estimate bone resorption

Table 2 The markers of bone and calcium metabolism in patients and controls (mean \pm S.D. or median with ranges).

\begin{tabular}{lll}
\hline & \multicolumn{1}{c}{ Patients } & \multicolumn{1}{c}{ Controls } \\
\hline Serum albumin-corrected calcium $(\mathrm{mmol} / \mathrm{l})$ & $2.45 \pm 0.10$ & $2.46 \pm 0.08$ \\
Serum phosphate $(\mathrm{mmol} / \mathrm{l})$ & $1.05 \pm 0.17$ & $1.08 \pm 0.13$ \\
Serum magnesium $(\mathrm{mmol} / \mathrm{l})$ & $0.87 \pm 0.08$ & $0.90 \pm 0.07$ \\
Serum $25-\mathrm{OH}-\mathrm{D}(\mathrm{nmol} / \mathrm{l})$ & $64 \pm 22$ & $62 \pm 21$ \\
Serum $1,25-(\mathrm{OH}))_{2}-\mathrm{D}(\mathrm{pmol} / \mathrm{l})$ & $106(55-218)$ & $111(72-204)$ \\
Serum $\mathrm{PTH}(\mathrm{ng} / \mathrm{l})$ & $39(16-77)$ & $30(13-56)$ \\
Urinary calcium $(\mathrm{mmol} / 24 \mathrm{~h})$ & $3.6 \pm 1.7$ & $3.4 \pm 1.8$ \\
Urinary phosphate $(\mathrm{mmol} / 24 \mathrm{~h})$ & $32 \pm 10^{*}$ & $26 \pm 8$ \\
Urinary magnesium $(\mathrm{mmol} / 24 \mathrm{~h})$ & $5.0 \pm 1.8^{*}$ & $3.9 \pm 1.4$ \\
Urinary creatinine $(\mathrm{mmol} / 24 \mathrm{~h})$ & $10.3(8.6-18.4)^{* *}$ & $8.5(4.9-13.4)$ \\
\hline
\end{tabular}

${ }^{*} P<0.05,{ }^{* *} P<0.01$ for differences between patients and controls.

Table 3 The markers of bone turnover (mean \pm S.D. or median with ranges) in pre- and postmenopausal female patients and respective controls.

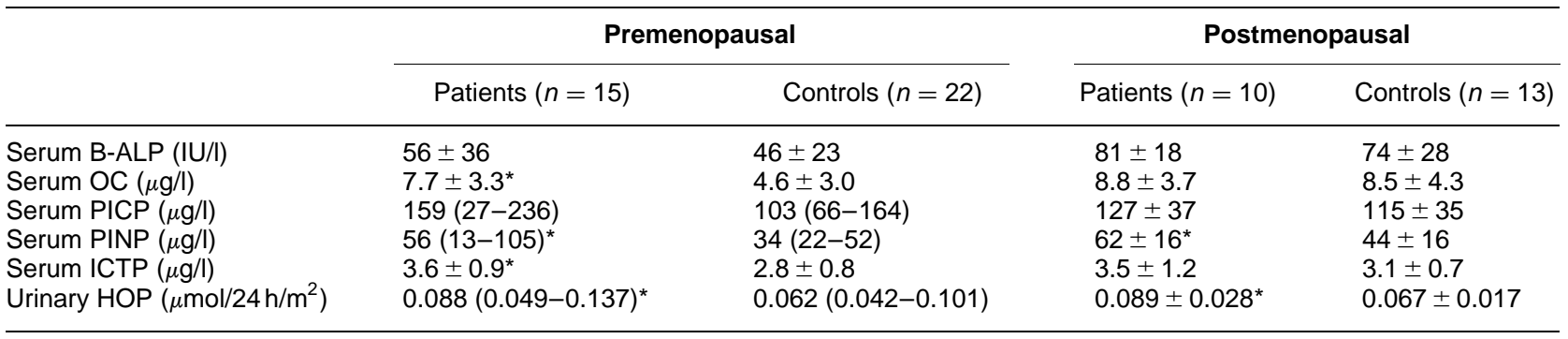

\footnotetext{
${ }^{*} P<0.05$ for differences between patients and controls.
} 
Table 4 Bone mineral density (mean \pm S.D.; $\mathrm{g} / \mathrm{cm}^{2}$ ) in the whole patient group, pre- and postmenopausal female patients and respective controls.

\begin{tabular}{|c|c|c|c|c|c|c|}
\hline & \multirow[b]{2}{*}{$\begin{array}{c}\text { All patients } \\
(n=29)\end{array}$} & \multirow[b]{2}{*}{$\begin{array}{l}\text { Controls } \\
(n=38)\end{array}$} & \multicolumn{2}{|c|}{ Premenopausal } & \multicolumn{2}{|c|}{ Postmenopausal } \\
\hline & & & $\begin{array}{l}\text { Patients } \\
(n=15)\end{array}$ & $\begin{array}{l}\text { Controls } \\
(n=22)\end{array}$ & $\begin{array}{l}\text { Patients } \\
(n=10)\end{array}$ & $\begin{array}{l}\text { Controls } \\
(n=12)\end{array}$ \\
\hline Lumbar spine & $0.997 \pm 0.144$ & $0.997 \pm 0.134$ & $1.082 \pm 0.131$ & $1.084 \pm 0.077$ & $0.876 \pm 0.084$ & $0.891 \pm 0.129$ \\
\hline Femoral neck & $0.840 \pm 0.144$ & $0.807 \pm 0.104$ & $0.892 \pm 0.141$ & $0.861 \pm 0.094$ & $0.733 \pm 0.096$ & $0.736 \pm 0.094$ \\
\hline Trochanter & $0.704 \pm 0.100$ & $0.727 \pm 0.108$ & $0.742 \pm 0.094$ & $0.758 \pm 0.107$ & $0.630 \pm 0.094$ & $0.673 \pm 0.082$ \\
\hline Ward's triangle & $0.602 \pm 0.155$ & $0.623 \pm 0.147$ & $0.693 \pm 0.127$ & $0.721 \pm 0.123$ & $0.447 \pm 0.050$ & $0.506 \pm 0.095$ \\
\hline
\end{tabular}

(deoxypyridinoline, C-telopeptide, N-telopeptide), a range of biochemical markers was employed to evaluate bone formation rate. This set included serum PINP assayed with the most recent and reliable technique for intact PINP (13); older technology for PINP measurements has not yielded adequate information about the rate of bone formation (18).

After therapy for hyperthyroidism the increased levels of markers of bone formation and resorption returned to normal within one month (5). Except for serum PICP, this also occurred in the present patients five weeks after withdrawing thyroxine treatment. Interestingly, during the development of hypothyroidism the serum concentrations of PICP and PINP behaved differently; the former clearly increased, whereas the latter decreased slightly. During bone formation PICP and PINP are stoichiometrically released from type I procollagen molecules; thus, slowing bone formation should lead to the decreased release of both these markers into the circulation. If this is the case, then the divergent behavior of PICP and PINP must result from differences in their rates of removal by the liver. PICP is eliminated from the circulation mainly via mannose receptors on liver endothelial cells (19), whereas PINP is cleared by the same cells of the liver via the scavenger receptor (20). Hypothyroidism may differentially affect the function of these two receptors and, consequently, the removal of
PICP and PINP, thus providing an explanation for their divergent behavior.

In keeping with previous findings (21), the serum concentration of 1,25-dihydroxyvitamin D increased during developing hypothyroidism. Thyroid hormones inhibit the renal production of $1,25(\mathrm{OH})_{2}-\mathrm{D}$; consequently, in hypothyroidism this production increases (22). Although 1,25-dihydroxyvitamin D stimulates osteoblasts to produce osteocalcin (23), the concentration of this marker of bone formation decreased together with a slow down in bone turnover despite the simultaneous increase in $1,25(\mathrm{OH})_{2}$-D levels.

The present study population was comprised predominantly of premenopausal women, but even in a subgroup of 10 postmenopausal women with normal $\mathrm{BMD}$ we could not agree with the conclusion of the recent meta-analysis that postmenopausal women on thyroxine suppressive treatment are at risk of accelerated bone loss (1). We would like, however, to make one point. In few studies has the significance of calcium intake been taken into account when the untoward effects on bone of thyroxine suppressive therapy have been addressed. In a study by Kung et al. (10) postmenopausal women on thyroxine suppressive therapy and with a mean daily calcium intake of $545 \mathrm{mg}$, had lower BMD in the lumbar spine, femoral neck, trochanter and Ward's triangle compared with controls. In a recent prospective study by the same
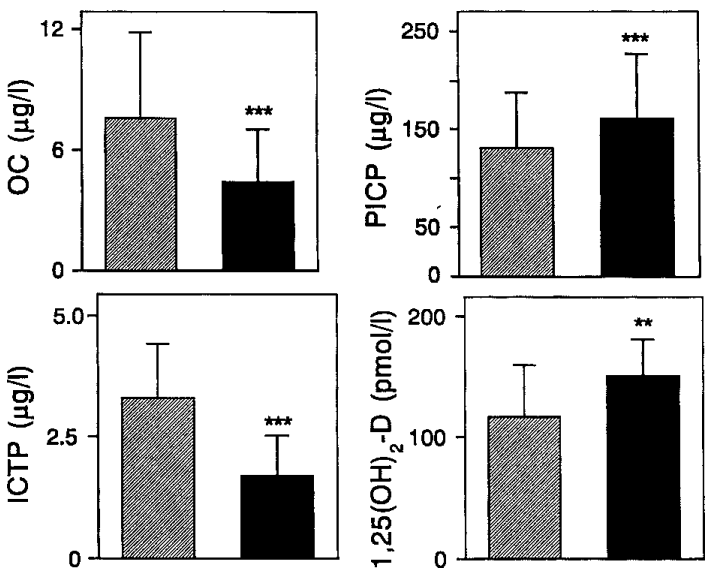

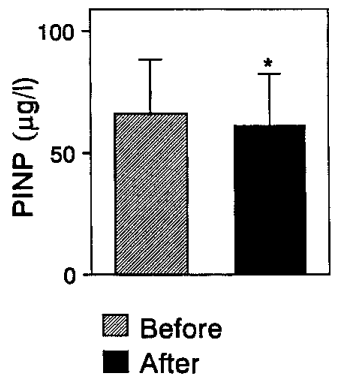

Figure 3 Parameters of bone and calcium metabolism (mean \pm S.D.) before and after interruption of $\mathrm{LT}_{4}$ therapy for 5 weeks. ${ }^{*} P<0.05,{ }^{* *} P<0.01$, ${ }^{* *} P<0.001$ for differences between values with and without thyroxine. 


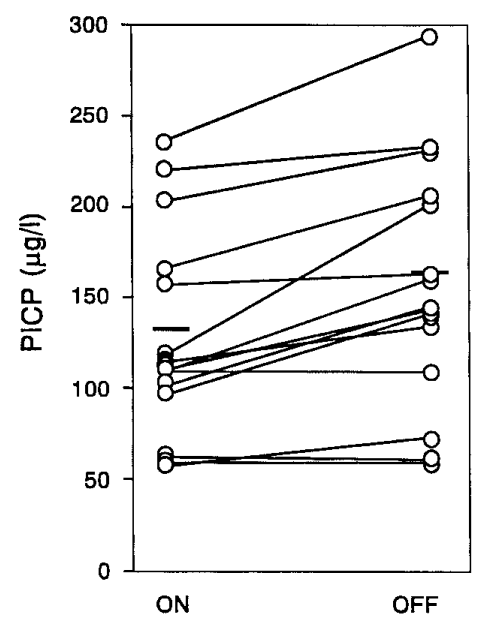

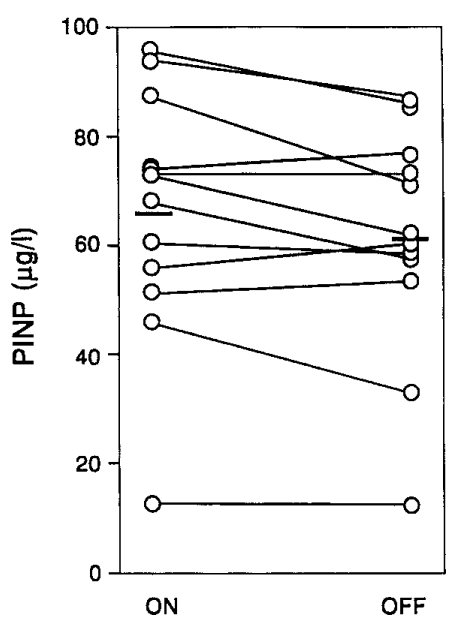

Figure 4 PICP and PINP values for individual patients before and after interruption of $\mathrm{LT}_{4}$ therapy for five weeks. The bars indicate the mean values. authors, thyroxine-induced bone loss was totally prevented when postmenopausal women increased their mean daily calcium intake from $0.5 \mathrm{~g}$ to $1.5 \mathrm{~g}$ (24); the increased serum levels of osteocalcin were also normalized. Thus, bone loss induced by thyroxine suppressive therapy may be less significant in those populations, such as the Finnish one, which have a high basal calcium intake of $0.9-1.2 \mathrm{~g}$ daily $(25,26)$. Thus, despite increased bone turnover, if there is sufficient calcium intake, bone formation may meet the demands of bone resorption better, and osteoporosis does not ensue.

We conclude that patients on $\mathrm{LT}_{4}$ suppressive therapy have a high bone turnover rate, which may increase their risk for osteoporosis. After withdrawal of $\mathrm{LT}_{4}$ treatment, both bone formation and resorption decrease acutely. Divergent behavior of serum PICP and PINP during development of hypothyroidism may be due to their removal through different receptors in the liver.

\section{Acknowledgements}

This study has been supported by a grant from the Finnish Cancer Research Foundation.

\section{References}

1 Faber J \& Galloe AM. Changes in bone mass during prolonged subclinical hyperthyroidism due to L-thyroxine treatment: a metaanalysis. European Journal of Endocrinology 1994130 350-356.

2 Bauer DC, Black DM, Ashby MA \& Cummings SR. Thyroid function and bone mass of the hip in postmenopausal women. Proceedings of the 4th International Symposium on Osteoporosis and Consensus Development, pp 170-171. Eds C Christiansen \& B Riis. Aalborg, Denmark: Handelstryhkerict Aalborg Aps, 1993.

3 Cummings SR, Nevitt MC, Browner WS, Stone K, Fox KM, Ensrud KE et al. Risk factors for hip fracture in white women. New England Journal of Medicine 1995332 767-773.

4 Solomon S \& Burman KD. The prevalence of bone fractures in women with thyroid disease. Thyroid 19933 17-23.

5 Garnero P, Vassy V, Bertholin A, Riou JP \& Delmas PD. Markers of bone turnover in hyperthyroidism and the effects of treatment. Journal of Clinical Endocrinology and Metabolism 199478 955-959.
6 Diamond T, Nery L \& Hales I. A therapeutic dilemma: suppressive doses of thyroxine significantly reduce bone mineral measurements in both premenopausal and postmenopausal women with thyroid carcinoma. Journal of Clinical Endocrinology and Metabolism 1990 72 1184-1188.

7 Ross DS, Ardisson LJ, Nussbaum SR \& Meskell MJ. Serum osteocalcin in patients taking L-thyroxine who have subclinical hyperthyroidism. Journal of Clinical Endocrinology and Metabolism 199172 507-509.

8 Harvey RD, McHardy KC, Reid IW, Paterson F, Bewsher PD, Duncan A et al. Measurement of bone collagen degradation in hyperthyroidism and during thyroxine replacement therapy using pyridinium cross-links as specific urinary markers. Journal of Clinical Endocrinology and Metabolism 199172 1189-1194.

9 Stepan JJ \& Limanova Z. Biochemical assessment of bone loss in patients on long-term thyroid hormone treatment. Bone and Mineral 199217 377-388.

10 Kung AWC, Lorentz T \& Tam SCF. Thyroxine suppressive therapy decreases bone mineral density in post-menopausal women. Clinical Endocrinology 199339 535-540.

11 Marcocci C, Golia F, Bruno-Bossio G, Vignali E \& Pinchera A. Carefully monitored levothyroxine suppressive therapy is not associated with bone loss in premenopausal women. Journal of Clinical Endocrinology and Metabolism 199478 818-823.

12 Liewendahl K, Tikanoja S, Helenius T \& Välimäki M. Discrepancies between serum free triiodothyronine and free thyroxine as measured by equilibrium dialysis and analog radioimmunoassays in nonthyroidal illnesses. Clinical Chemistry 198430 760-762.

13 Melkko J, Kauppila S, Niemi S, Risteli L, Haukipuro K, Jukkola A et al. Immunoassay for intact aminoterminal propeptide of human type I procollagen. Clinical Chemistry 199642 947-954.

14 Risteli J, Elomaa I, Niemi S, Novamo A \& Risteli L. Radioimmunoassay for the pyridinoline cross-linked carboxyterminal telopeptide of type I collagen: a new serum marker of bone collagen degradation. Clinical Chemistry 199339 635-640.

15 Rosalki SB \& Foo AY. Two new methods for separating and quantifying bone and liver alkaline phosphatase in plasma. Clinical Chemistry $1984301182-1186$.

16 Prockop DJ \& Udenfriend S. A specific method for the analysis of hydroxyproline in tissues and urine. Analytical Biochemistry 1960 $1228-239$

17 Schneider DL, Barrett-Connor EL \& Morton DJ. Thyroid hormone use and bone mineral density in elderly women. Effects of estrogen. Journal of the American Medical Association 1994271 1245-1249.

18 Ebeling PR, Peterson JM \& Riggs BL. Utility of type I procollagen propeptide assays for assessing abnormalities in metabolic bone diseases. Journal of Bone and Mineral Research 19927 1243-1250. 
19 Smedsrod B, Melkko J, Risteli L \& Risteli J. Circulating carboxyterminal propeptide of type I procollagen is cleared mainly via the mannose receptor in liver endothelial cells. Biochemical Journal 1990271 345-350.

20 Melkko J, Hellevik T, Risteli L, Risteli J \& Smedsrod B. The aminoterminal propeptide of type I procollagen is a physiological ligand for the scavenger receptor of the endothelial cells of the liver Journal of Experimental Medicine 1994179 405-412.

21 Bouillon R, Muls E \& De Moor P. Influence of thyroid function on the serum concentration of 1,25-dihydroxyvitamin $\mathrm{D}_{3}$. Journal of Clinical Endocrinology and Metabolism 198051 793-797.

22 Kano K \& Jones G. Direct in vitro effect of thyroid hormones on 25 hydroxyvitamin $\mathrm{D}_{3}$ metabolism in the perfused rat kidney. Endocrinology 1984114 330-336.

23 Price PA \& Baukol SA. 1,25-Dihydroxyvitamin $\mathrm{D}_{3}$ increases synthesis of the vitamin K-dependent bone protein by osteosarcoma cells. Journal of Biological Chemistry 1980255 11660-11663.
24 Kung AWC \& Yeung SSC. Prevention of bone loss induced by thyroxine suppressive therapy in postmenopausal women: the effect of calcium and calcitonin. Journal of Clinical Endocrinology and Metabolism 199681 1232-1236.

25 Laitinen K, Kärkkäinen M, Lalla M, Lamberg-Allardt C, Tunninen $\mathrm{R}$, Tähtelä $\mathrm{R}$ et al. Is alcohol an osteoporosis-inducing agent for young and middle-aged women? Metabolism 199342 875-881.

26 Laitinen K, Välimäki M, Lamberg-Allardt C, Kivisaari L, Lalla M, Kärkkäinen $\mathrm{M}$ et al. Deranged vitamin $\mathrm{D}$ metabolism but normal bone mineral density in Finnish noncirrhotic male alcoholics. Alcoholism: Clinical and Experimental Research 1990 $14551-556$.

Received 25 August 1997

Accepted 5 February 1998 